\title{
Zootheraputic practices in Swabi district of Khyber Pakhtunkhawa Pakistan
}

\author{
Waqas Ahmad Shams ${ }^{1 *}$, Gauhar Rehman ${ }^{1}$, Zahid Ullah ${ }^{2}$, Sumbal Ara ${ }^{1}$, \\ Sadaf Niaz ${ }^{1}$, Abid Ali ${ }^{1}$, Khurshid Khan ${ }^{1}$, Huma Alam ${ }^{1}$, Nida Gul ${ }^{1}$, \\ Tahira Naz ${ }^{1}$, Saif ul Islam ${ }^{3}$ and Abdul Jamil khan ${ }^{1}$ \\ 1. Department of Zoology, Abdul Wali Khan University Mardan Khyber Paktunkhwa-Pakistan \\ 2. Department of Zoology, University of Buner Khyber Paktunkhwa-Pakistan \\ 3. Department of Zoology, Government Degree College Lahor Swabi, Khyber Paktunkhwa-Pakistan \\ *Corresponding author's email: Wshams89@awkum.edu.pk \\ Citation \\ Waqas Ahmad Shams, Gauhar Rehman, Zahid Ullah, Sumbal Ara, Sadaf Niaz, Abid Ali, Khurshid Khan, Huma \\ Alam. Nida Gul, Tahira Naz, Saif ul Islam and Abdul Jamil Khan. Zootheraputic practices in Swabi district of \\ Khyber Pakhtunkhawa Pakistan. Pure and Applied Biology. Vol. 8, Issue 1, pp222-231.
}

http://dx.doi.org/10.19045/bspab.2018.700180

\begin{tabular}{llll}
\hline \hline Received: 22/07/2018 & Revised: 11/10/2018 & Accepted: 21/10/2018 & Online First: 02/11/2018 \\
\hline \hline
\end{tabular}

\section{Abstract}

The use of animals for therapeutic purpose is an important filed from ancient time. They utilize animals for different purposes like art, religion, music, and literature. In Zoo therapy different parts of the animal body, their products, or non-animal materials such as nests and cocoon are used. It has an important contribution to understanding traditional subsistence and medical knowledge and practices. The present study is intended to look into different zoo therapeutic medicinal uses in the traditional health care system among the native inhabitants of district Swabi, Khyber PakhtunKhawa Pakistan. It is of immense importance that 47 different types of animals species use for different type of diseases like cancer, diabetes, snake bite, fever etc. The part used, how they used and what is the Fidelity level (FL) and Relative frequency of citation (RFC) is the key points. This study highlights traditional zoo therapeutic remedial measures and verify it so that it used for the welfare of human on a commercial level.

Keywords: Ethno zoology; Fidelity level; Relative frequency of citation

\section{Introduction}

From the very beginning the peoples of different areas using plants and animals as Bio resources [1, 2]. In the modern health care system traditional medicinal knowledge is an important alternative in society i.e. about $70-80 \%$ of the world rural population depends on it [3]. The percentage of the population using traditional medicines for primary health care is more $(60-90 \%)$ in developing countries than that in developed countries (23-80\%) [4]. around $60 \%$ of commercially available drugs are based on bioactive compounds extracted from natural resources traditionally used by various indigenous cultures around the globe [5]. Although plants and plant derivatives have been used as a major constituent of traditional medicine, the identification of animal resources for a medicinal cure is also important in human health care $[1,6]$. The healing of human ailments by using animals or products of animals is called Zootherapy. The use of animals for the therapeutic purpose is an important filed from ancient time. In Zoo therapy different parts of the 
animal body, their products, or non-animal materials such as nests and cocoon are used. It has an important contribution to understanding traditional subsistence and medical knowledge and practices [7,8].

The zootherapeutic practices ratio are different in different parts of the world e.g. In Latin America, 584 animals distributed are used for traditional therapeutic medicinal value [9], 283 animal species are used in Brazil [10, 11], 180 animal species were recorded in the semi-arid region of Northeastern Brazil, Toba (Qom) communities of Argentine Gran Chaco region use 72 animal $[12,13]$. In the whole world, China is on top in use of the animals for the traditional purpose. They use more than 1500 animal species for medicinal importance [14]. In Israel, the use was limited to 20 animal species as traditional drugs [Lev and Amar (2000). Our neighbor country India has a great faunal diversity accounting for about $10 \%$ of the reported biological species. 15-20 percent of Ayurvedic medicine is based on animal-derived substances [15]. It is hoped that by additional research the zoo therapeutic will be increased.

In Zoo therapy Mostly vertebrates were used. It does not mean that invertebrates are of no significance. A number of invertebrates are of main importance like the honey bee, silkworm etc. In vertebrates mammals, birds, fishes, and reptiles are of main importance. Amphibians are less commonly used among medicinal vertebrates. Ulysses et al reported that at least 165 species of reptiles, 101 species of primates. 55 species of Bovidae and 46 carnivorous mammals used in zoo therapy [16].

Many studies have been undertaken on Zoo therapy. However, there is no report available about its ethnozoology of district Swabi, Khyber Pakhtun Khawa Pakistan. Present study highlights and verify for the welfare of human on the commercial level.

\section{Materials and methods Study area}

This paper explains the zootherapeutic in Swabi district of Khyber Paktun Khwa, Pakistan is given. This information was collected during the field survey on ethno zoology uses for the Ph.D. thesis. A brief summary of a district is given. The information was collected from 210 interviewers most of them know about plant uses but some of them (10\%) given information about zoo therapy.

\section{Methodology}

Before starting the survey a Questionnaire was formed. In Questionnaire different question was included like a local name of the animal, part used, for which disease it is used, how it prepared, route of administration, the dose used, time of treatment etc. The age of respondents varied from 30 to 62 years. 210 interviewers were included in this study. The interviewers were selected on the basis of their experience, recognition as an expert knowledgeable persons, traditional healers concerning traditional medicine. All the ingredients were noted thoroughly, using standard literature, scientific name and species name of animals was identified [17, 18].

\section{Data analysis}

The method used by Manash and Surya 2017 were used with little modification [19]. Relative frequency of citation shows the native reliance on each species. The following formula use for their calculation.

$\mathrm{RFC}=\mathrm{FC} / \mathrm{N}$

FC denotes the number of interviewer mentioning the use of the species and $\mathrm{N}$ is total number of interviewer [20]. This RFC index is in between 0 to 1 . When RFC is 0 , it means no interviewer given information about the animal usefulness and when RFC is 1 , it shows that all given information about the animal usefulness [21]. 


\section{Fidelity level}

Fidelity level is used for the determination of animals used for the treatment of specific disease. It shows that most of the inhabitant of this area use specie for treating certain diseases. Fidelity level is calculated by Mootsamy and Mahomoodly 2014 formula as given below:

$\mathrm{FL}(\%)=\mathrm{Np} \times 100 / \mathrm{N}$

Where $\mathrm{Np}$ is denotes the number of interviewer mentioning the use of the species to treat a specific disease and $\mathrm{N}$ total number of interviewer who used the animals as a medicine to treat any given disease.

\section{Results and discussion \\ Demographic details of interviewer}

The inhabitants of Swabi district have great knowledge of animals and plants used for different diseases. They use it in their own ways and beliefs. Most of the interviewer were local practitioners known as Hakeem. Demographic information of the respondents was collected through face to face interaction. During the survey, respondents comprised an uneven distribution of the male-female ratio, $99.80 \%$ were male interviewers. The same trend was also reported in other studies [22, 23]. The respondents or local practitioners were selected and interviewed in different the Tehsils of Swabi district. The age of respondents varied from 30 to 62 years. The percentage of a local medicinal practitioner with age lower than fifty was found to be very less with only $21 \%$ as compared to $79 \%$ of the age group of society above 50 years. The demographic details in the table show that the old local practitioners are more knowledgeable than younger ones [24]. Most of these local practitioners have knowledge of Zootherapy from their elder's one. The reason for less traditional medicinal knowledge among the younger generation could be due to urbanization and the assimilation of alien culture. Most of the secondary level education while some of them were up to graduation level (Table 1). Only 12 respondents $(19.4 \%)$ were formally employed in government sector mainly as school teachers while others were mostly farmers, workers and local traditional healers. Most of the informants practiced this traditional therapy as a part-time job to serve the society. However, some are renowned well-known herbalist/healers who practice this traditional medicinal knowledge in large scale as their profession.

Table 1. Demographic profile of the informants included in survey $(\mathrm{N}=51)$

\begin{tabular}{|c|c|c|}
\hline \multicolumn{1}{|c|}{ Number of people } & Percentage \\
\hline \multicolumn{2}{|c|}{ Gender } \\
\hline Male & 49 & 98.80 \\
\hline Female & 2 & 1.20 \\
\hline & Education & 13.72 \\
\hline Primary Education & 7 & 37.25 \\
\hline Secondary Education & 19 & 41.17 \\
\hline Graduate & 21 & 7.83 \\
\hline Extra Qualification & 4 & 13.72 \\
\hline & Age Of Traditional Healer & 41.17 \\
\hline $31-40$ & 7 & 49.01 \\
\hline $41-50$ & 21 & 3.92 \\
\hline $51-62$ & 25 & \\
\hline $62>$ & 2 & \\
\hline
\end{tabular}


Ethnozoological analysis

About 46 animal's recorded in this study. They used to treat 47 diseases as summarizes in (Table 2). They are given under name of phylum, English name, scientific name, local name, the parts or byproduct of the species used to treat the disease. These belongs to both vertebrates (37 species) and invertebrates (15 species).the study reveals that mostly the peoples and healers of this district use insect .The second highest zoo therapeutic animals to be used are mammals as some of them are domesticated animals (Figure 1).

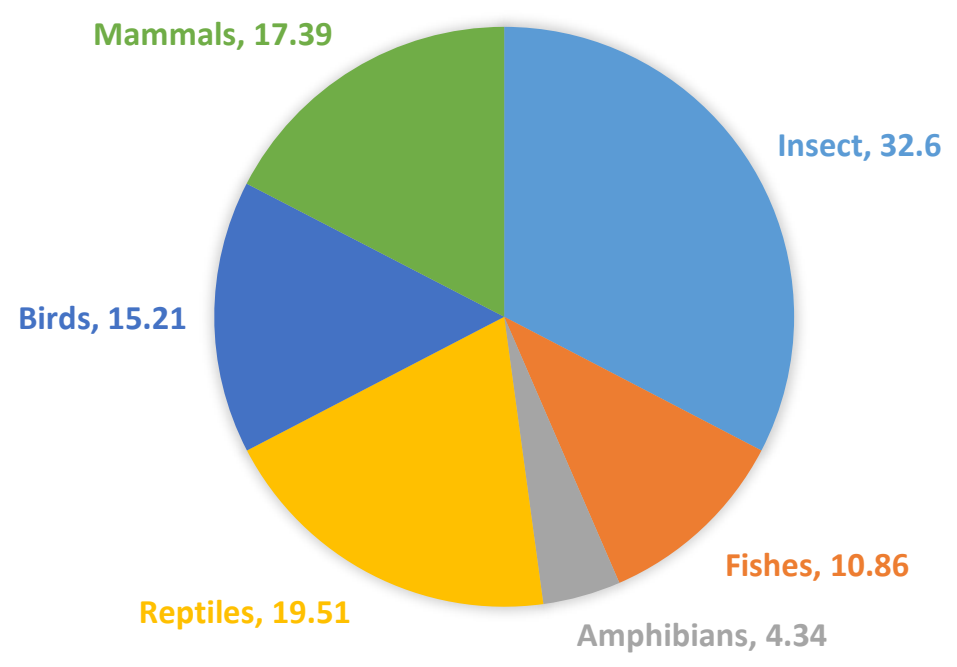

Figure 1. Percentage of animal categories being used in zoo therapeutic practices among the traditional healers in the district Swabi

From the current study it is concluded that animals is used for treatment of different diseases like diabetes. Asthma, pneumonia, piles, gastric, fever. Snake bite, cancer, Pox, etc. The use of whole animals for medicinal purpose was recorded to be the highest (36.11\%), followed by other animals parts and byproducts like meat (11.5\%), blood, head, alimentary canal, gall bladder/bile, horn, milk (each $8.1 \%$ ) and heart, cocoon with larva (3.79\%). it is mostly used orally than topically (Figure 2).

The present study showed that 7 modes of preparation for consumption used against diseases.in Raw form $29.9 \%$, boiled $10.2 \%$, cooked $6.2 \%$, juice $4.3 \%$ ), paste $9.2 \%$, fried $26.1 \%$, and smoke $(21.1 \%$ (Figure 3 ). Vijay Kumar et al., 2015 also found that raw materials mostly used for therapeutic purpose [2].

\section{Quantitative analysis}

Relative frequency of citation (RFC)

RFC index was determined for finding out the importance of each species. The RFC Valve of Assamese snakehead fish was 0.67, which is highest among all. The lowest valve was 0.12 for Slenderan. The lowest valve of RFC does not means that it is of less importance but it shows that most of the peoples did not know about their uses. 


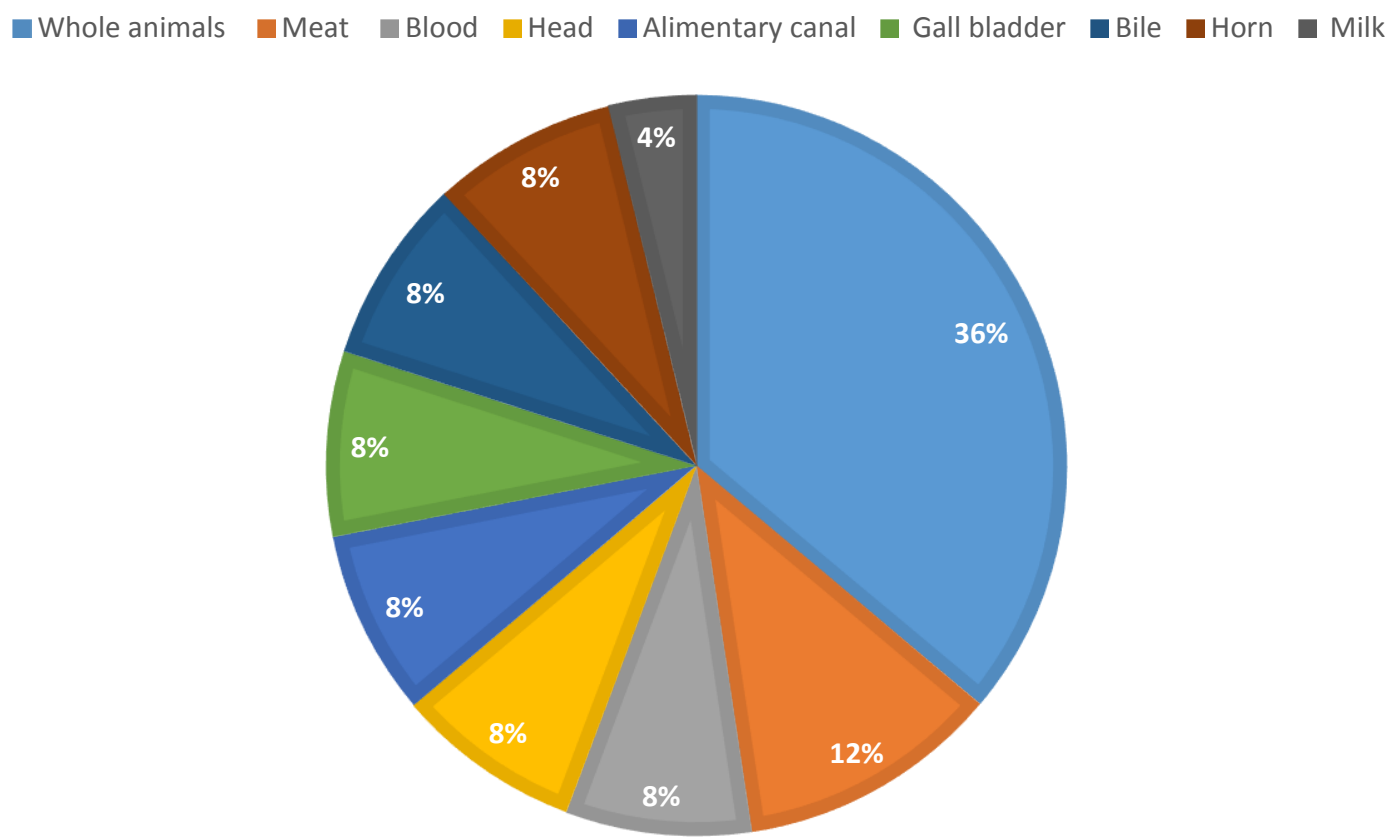

Figure 2. The use of whole animal and parts for Zootherpeutic purpose

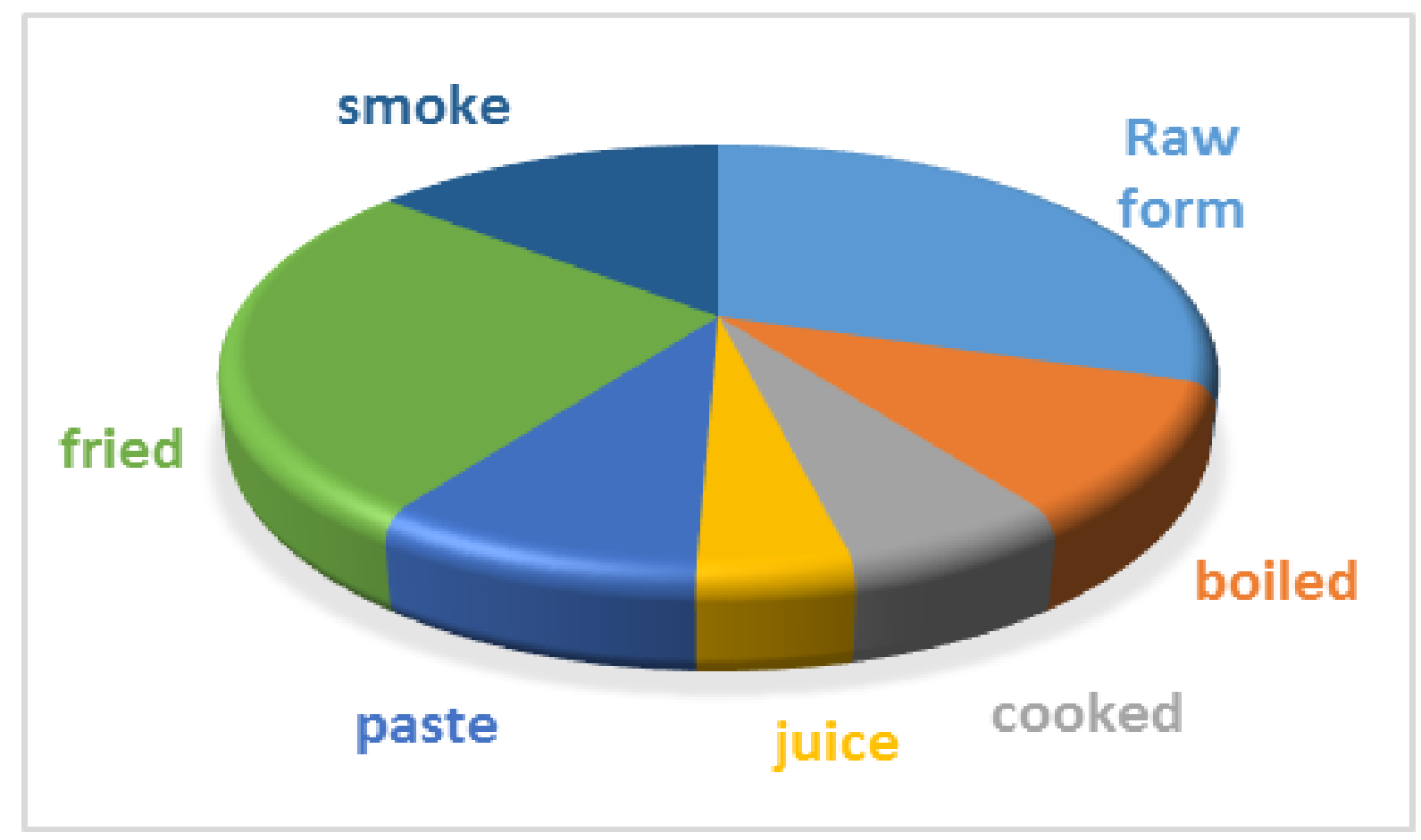

Figure 3. Methods of preparation of different animals and animals parts (\%) 
Shams et al.

Table 2. Ethno zoological record of district Swabi Khyber Paktunkhwa, Pakistan

\begin{tabular}{|c|c|c|c|c|c|c|c|c|c|}
\hline $\begin{array}{l}\text { S. } \\
\text { No. }\end{array}$ & $\begin{array}{l}\text { Animal } \\
\text { group }\end{array}$ & English name & Scientific name & Local name & Body parts used & Midicnal use & Application & RFC & $\begin{array}{r}\% \\
\text { FL }\end{array}$ \\
\hline 1 & Insect & Crab & Allocantus yawi & Keekrha & $\begin{array}{l}\text { Whole } \\
\text { body }\end{array}$ & $\begin{array}{l}\text { Used as massage cream in muscular } \\
\text { pain. anti-diabetes }\end{array}$ & Topical & 0.23 & 33.3 \\
\hline 2 & Insect & Honey bee & Apis indica & $\begin{array}{c}\text { Shahid ki } \\
\text { makki }\end{array}$ & Honey & $\begin{array}{c}\text { Eye disease Used as eye drops to cure } \\
\text { eye disease }\end{array}$ & Topical & 0.11 & 98.9 \\
\hline 3 & Insect & Crickets & Achaeta sp. & keekhra & Hind legs & Antidiuretic and for anti-diabetes & Oral & 0.26 & 67.3 \\
\hline 4 & Insect & Cockroaches & $\begin{array}{c}\text { Periplaneta } \\
\text { americana }\end{array}$ & Laalbaig & Whole body & Asthma & Oral & 0.51 & 56.1 \\
\hline 5 & Insect & Housefly & $\begin{array}{c}\text { Musca } \\
\text { domestica }\end{array}$ & Makki & Whole body & Baldness/ Bronchitis & Oral & 0.21 & 40.1 \\
\hline 6 & Insect & Leaf-cutting ant & Atta.sp & Chewenti & Whole body & Tendinitis & $\begin{array}{c}\text { Oral/ } \\
\text { Topical }\end{array}$ & 0.18 & 32.1 \\
\hline 7 & Insect & Stingless bee & Melipona sp. & $\begin{array}{l}\text { Madoo } \\
\text { makki }\end{array}$ & Honey & Throat inflammation & Topical & 0.15 & 47.4 \\
\hline 8 & Insect & Stingless bee & $\begin{array}{l}\text { Trigona } \\
\text { spinipes }\end{array}$ & $\begin{array}{c}\text { Madoo } \\
\text { makki }\end{array}$ & Honey scuitellium & Acne, influenza, stroke & Topical & 0.14 & 76.2 \\
\hline 9 & Insect & Scorpian & Tytius sp & Bichoo & sting & $\begin{array}{c}\text { For to treat its own sting and for skin } \\
\text { diseases }\end{array}$ & Topical & 0.25 & 32.3 \\
\hline 10 & Insect & Dragon fly & anisoptera & anax & Feathers & Anti-cancer & Oral & 0.21 & 54.5 \\
\hline 11 & Insect & Green tree ant & $\begin{array}{l}\text { Oecphyllas } \\
\text { maragdina }\end{array}$ & $\begin{array}{l}\text { Tamoli } \\
\text { paruwa }\end{array}$ & Whole body & $\begin{array}{c}\text { Sinus Cancer Epistasis } \\
\text { (Bleeding from nose) }\end{array}$ & Topical & 0.21 & 43.2 \\
\hline 12 & Insect & Rice bug & $\begin{array}{c}\text { Leptocorisa } \\
\text { varicornis }\end{array}$ & Gandhi kira & Whole body & Fever & Oral & 0.22 & 76.4 \\
\hline 13 & Insect & Silk worm & Anth mensis & Muga palu & Whole body & Weakness & Topical & 0.27 & 53.4 \\
\hline 14 & Insect & House cricket & $\begin{array}{c}\text { Achetado } \\
\text { mestica }\end{array}$ & Uisiringa & Whole body & Pain improve pencrease & Oral & 0.28 & 87.1 \\
\hline 15 & Insect & Bombardier beetle & Heropsophus & Poda paruwa & Whole body & Alcoholic habbit & $\begin{array}{c}\text { Oral/ } \\
\text { Topical }\end{array}$ & 0.27 & 31.4 \\
\hline 16 & Fishes & Labeo Fish & Labeo rohia & Machli & $\begin{array}{l}\text { Cervical } \\
\text { vertebrae }\end{array}$ & $\begin{array}{l}\text { Fish cervical vertebra is rubbed with } \\
\text { water and this essence water is taken } \\
\text { in urine blockage problem }\end{array}$ & Oral & 0.37 & 11.2 \\
\hline 17 & Fishes & $\begin{array}{l}\text { Assamese } \\
\text { snakehead } \\
\text { fish } \\
\end{array}$ & Channastewartii & $\begin{array}{l}\text { Chengeli } \\
\text { mas }\end{array}$ & Whole body & Diabetes/ Bronchitis & Oral & 0.67 & 32.1 \\
\hline 18 & Fishes & Magurma fish & Clariasbatrachus & Magur & Whole body & Body ache & Topical & 0.54 & 21.5 \\
\hline
\end{tabular}




\begin{tabular}{|c|c|c|c|c|c|c|c|c|c|}
\hline 19 & Fishes & Roumas fish & Labeorohita & Rohu & Gall bladder (bile) & Gastric & Oral & 0.42 & 32.1 \\
\hline 20 & Fishes & Prawn & $\begin{array}{l}\text { Macrobrachium } \\
\text { malcolmsonii }\end{array}$ & Jingha & Dried powder & tuberculosis & Oral & 0.27 & 21.1 \\
\hline 21 & $\begin{array}{l}\text { Amphibi } \\
\text { ans }\end{array}$ & Toad & Bufo sp & Maindak & Skin/oil & Diabetes, Urinary retention & Topical & 0.05 & 32.2 \\
\hline 22 & $\begin{array}{l}\text { Amphibi } \\
\text { ans }\end{array}$ & Frog & $\begin{array}{c}\text { Euphlyctis } \\
\text { cyanophlyctis }\end{array}$ & Maindak & Skin/oil & Diabetes, Anticancer & Topical/Oral & 0.53 & 45.5 \\
\hline 23 & Reptiles & $\begin{array}{l}\text { Hard shelled } \\
\text { Turtle } \\
\end{array}$ & $\begin{array}{c}\text { Kachuga } \\
\text { tentoria } \\
\end{array}$ & Kechwa & Carapace Flesh & For chicken pox & Oral & 0.46 & 43.3 \\
\hline 24 & Reptiles & Lizard & $\begin{array}{c}\text { Tropidurus } \\
\text { torquatus }\end{array}$ & Chipkali & Whole body & Rheumatism & Oral & 0.52 & 65.1 \\
\hline 25 & Reptiles & Snake & Russell's viper & Saamp & Venome & For chicken pox & Topical & 0.41 & 43.2 \\
\hline 26 & Reptiles & $\begin{array}{l}\text { Chameleon } \\
\text { Chameleon }\end{array}$ & $\begin{array}{l}\text { Chameleon } \\
\text { zeylanicus }\end{array}$ & Dagdaga & Tail & $\begin{array}{l}\text { Elephantiasis Bound around leg to } \\
\text { cure this problem }\end{array}$ & Oral & 0.11 & 27.5 \\
\hline 27 & Reptiles & Greater rhea & Rhea Americana & Naja saanp & Fat & Anticancer, for pain in muscles & topical & 0.27 & 59.6 \\
\hline 28 & Reptiles & Uromastix & $\begin{array}{l}\text { Uromastyx } \\
\text { hardwickii }\end{array}$ & Barti chpkali & Back bones & Diabetes & oral & 0.13 & 28.3 \\
\hline 29 & Reptiles & Slenderan & $\begin{array}{c}\text { Tetraponera } \\
\text { rufonigera }\end{array}$ & $\begin{array}{l}\text { Mojali } \\
\text { pruwa }\end{array}$ & Whole body & Body ache & Topical & 0.12 & 19.4 \\
\hline 30 & Reptiles & Praying mantis & Mantisre ligiosa & $\begin{array}{l}\text { Gaigini } \\
\text { foring }\end{array}$ & $\begin{array}{l}\text { Cocoon with larva } \\
\text { Whole insect Whole } \\
\text { body }\end{array}$ & Wound in ear Pneumonia & Oral & 0.22 & 11.2 \\
\hline 31 & Reptiles & Stinging cat & $\begin{array}{l}\text { Heteropneustes } \\
\text { fossils } \\
\end{array}$ & Singhimas & Whole body & Pain & Topical & 0.27 & 23.4 \\
\hline 32 & Birds & Pigeon & Columbus livia & Kabutar & $\begin{array}{l}\text { meat, fresh blood, } \\
\text { feather }\end{array}$ & Paralysis & Topical & 0.39 & 76.1 \\
\hline 33 & Birds & Indian pea fawl & Pavo cristatus & Mor & Feather, meat & Diabetes & Oral & 0.71 & 34.5 \\
\hline 34 & Birds & $\begin{array}{l}\text { Sparrow Bird } \\
\text { eating spider }\end{array}$ & Theraphosidae & Parinda & Feather, meat & Magic ritual & Topical & 0.12 & 23.3 \\
\hline 35 & Birds & Chicken & $\begin{array}{c}\text { Gallus } \\
\text { domesticus }\end{array}$ & Murghi & $\begin{array}{c}\text { White of the egg Fat } \\
\text { Body Soup }\end{array}$ & $\begin{array}{c}\text { Nasal congestion to stop bleeding } \\
\text { dysentery coughing }\end{array}$ & Oral & 0.56 & 32.5 \\
\hline 36 & Birds & Ground-dove & Leptotila sp. & Fahta & Feathers. meat & $\begin{array}{l}\text { Stroke } \\
\end{array}$ & Topical & 0.11 & 22.2 \\
\hline 37 & Birds & Jungle fowl & $\begin{array}{c}\text { Gallus } \\
\text { sonnerati }\end{array}$ & $\begin{array}{l}\text { Jangli } \\
\text { Murga }\end{array}$ & Testis & Male impotency Organ use orally & Oral & 0.23 & 54.2 \\
\hline 38 & Birds & House sparrow & $\begin{array}{c}\text { Passer } \\
\text { Domestica } \\
\end{array}$ & Gaonrani & Nest & $\begin{array}{l}\text { Nest Ellery Fume apply in whole } \\
\text { body covered with blanket }\end{array}$ & Topical & 0.37 & 23.3 \\
\hline 39 & $\begin{array}{c}\text { Mammal } \\
\mathrm{s} \\
\end{array}$ & Goat & Capra indicus & Bakkri & Milk, meat & For oral diseases & $\begin{array}{c}\text { Oral } \\
\text { /Topical } \\
\end{array}$ & 0.54 & 54.5 \\
\hline
\end{tabular}


Shams et al.

\begin{tabular}{|c|c|c|c|c|c|c|c|c|c|}
\hline 40 & $\begin{array}{l}\text { Mammal } \\
\mathrm{s}\end{array}$ & Sheep & Capra.sp & bairh & Milk meat & For muscular pain & Oral & 0.48 & 67.8 \\
\hline 41 & $\begin{array}{l}\text { Mammal } \\
\mathrm{s}\end{array}$ & Bird eating spider & Theraphosidae & Parinda & Feather & Magic ritual & & 0.72 & 51.4 \\
\hline 42 & $\begin{array}{l}\text { Mammal } \\
\mathrm{s}\end{array}$ & Lizard & $\begin{array}{l}\text { Tropidurus } \\
\text { torquatus }\end{array}$ & Chipkali & Whole body & For chicken pox & Topical & 0.29 & 43.7 \\
\hline 43 & $\begin{array}{l}\text { Mammal } \\
\mathrm{s}\end{array}$ & Chicken & $\begin{array}{c}\text { Gallus } \\
\text { domesticus }\end{array}$ & Murghi & $\begin{array}{l}\text { White of the egg } \\
\text { Fat Body Soup }\end{array}$ & $\begin{array}{c}\text { Nasal congestion to stop bleeding } \\
\text { dysentery coughing }\end{array}$ & Topical & 0.65 & 32.2 \\
\hline 44 & $\begin{array}{l}\text { Mammal } \\
\mathrm{s}\end{array}$ & Ox & Bos torous & bail & Feaces, meat & To make mosquitoes go away & Topical & 0.61 & 62.8 \\
\hline 45 & $\begin{array}{l}\text { Mammal } \\
\mathrm{s}\end{array}$ & Indian bison & Bos gaurus & Jangli boda & Dung & Hair growth & Oral & 0.31 & 43.2 \\
\hline 46 & $\begin{array}{l}\text { Mammal } \\
\mathrm{s}\end{array}$ & Camel & $\begin{array}{c}\text { Camilous } \\
\text { domedarous }\end{array}$ & Ont & milk & Muscular pain & Oral & 0.65 & 56.7 \\
\hline
\end{tabular}




\section{Fidelity level (FL)}

FL level is used to determine that most frequent and easily used species. There valve varies from $1.0 \%$ to $100 \%$ on response of interviewers most used and reported. The highest valve indicates that it that it is reported by all of the respondents [25]. Honey bee FL is 98.9 and for Praying mantis lowest valve of FL is 11.2.

\section{Conclusion}

Current study is the first ever study in Pakistan on zoo therapeutics. This study will help to maintain and record the traditional zoo therapeutic medicine. This will also help in finding novel biological active compound and discovery of new drugs. It will maintain biodiversity conservation and management strategies of animal resources for sustainable use.

\section{Authors' contributions}

Designed the experiments: G Rehman \& WA Shams, Performed the field survey: Z Ullah \& WA Shams, H Alam, N Gul, T Naz, SU Islam \& AJ Khan, Analyzed the data: G Rehman , A Ali , K Khan \& WA Shams, Contributed reagents/ materials/ analysis tools: S Niaz \& S Ara, Wrote the paper: Z Ullah \& WA Shams.

\section{References}

1. Alves RRN \& Rosa IL (2005). Why study the use of animal products in traditional medicine. $J$ Ethnobiol Ethnomed 5: 53.

2. Vijaykumar S, Yabesh JEM, Prabhu S, Ayyanar M \& Damodaran R (2015). Ethnozoological study of animals used by traditional healers in the silent vally of Kerala. India J Ethnopharmacol 162: 296-305.

3. World Health Organization. (2014). Guideline on the conservation of medicinal plants. Geneva: 1993.1-38.

4. Crag GM \& Newman DJ (2013). Natural products: a continuing source of novel drugs leads. Biochemica Et Biophysica Acta 180: 3670-95.
5. Costa-Neto EM (2005). Animal-based medicines: biological prospection and the sustainable use of zootherapeutic resources. Annals Acad Bras Cienc 77: 33-43.

6. Costa-Neto EM (1999). Healing with animals in Feira de Santana city Bahia Brazil. J Ethnopharmacol 65: 225-30.

7. Alves RRN \& Alves HN (2011). The faunal drugstore: animal-based remedies used in traditional medicines in Latin America. J Ethnobiol Ethnomed 7: 1-43.

8. Sarmah R \& Saikia A (2016). Folklore medicine practiced by traditional healers of fringe village of gibbon wildlife sanctuary, Assam. India. Acta Biomedica Scientia 3(4): 227-33.

9. Alves RRN, Rosa IL \& Santana GG (2007). The role of animal-derived remedies as complementary medicine in Brazil. Bio Sci 57(11): 949-55.

10. Costa-Neto EM (2004). Implications and applications of folk zootherapy in the state of Bahia. Northeastern Brazil Sustain Dev 12(3): 161-74.

11. Alves RRN, Barbosa JAA, Santos SLDX, Souto WMS \& Barboza RRD (2011). Animal based remedies as complementary medicines in the semiarid region of northeastern Brazil. Evid Based Complement Alternat Med 1-15.

12. Martinez GJ (2013). Use of fauna in the traditional medicine of native Toba (qom) from the argentine gran Chaco region: An Ethnozoological and conservationist approach. Ethnobio Conserv 2: 1-43.

13. China National Corporation of Traditional and Herbal medicine (1995). Materia medica commonly used in China Beijing. China Beijing: Sci Press.

14. Alves RRN, Souto WMS, Barboza RRD \& Bezerra DMM (2010). Primates in traditional folk medicine: a world overview. Mammal Rev 40: 155-80. 
15. Lev E \& Amar Z (2000). Ethnopharmacological survey of traditional drugs sold in Israel at the end of the 20th century. J Ethnopharmacol 72: 191-205.

16. Alves RRN \& Rosa IL (2007). Zootherapeutic practices among fishing communities in North and Northeast Brazil: a comparison. J Ethnopharmacol 111: 82-103.

17. Ali S (1996). The book of Indian birds. Bombay. Natural History Society: Bombay.

18. Prater SH (1996). The book of Indian animals. Bombay Natural History Society.

19. Manash PB \& Surya BP (2017). Ethnozoological study of animals based medicine used by traditional healers and indigenous inhabitants in the adjoining areas of Gibbon Wildlife Sanctuary, Assam, India. $J$ of Ethnobiol and Ethnomed 13: 39.

20. Vitalini S, Iriti M, Puricelli C, Ciuchi D, Segale A \& Fico G (2012). Traditional knowledge on medicinal and food plants used in Val san Giacomo (Sondrio,
Italy): An alpine ethnobotanical study. $J$ Ethnopharmacol 145: 517-29.

21. Mootsamy A, \& Mahomoodly MF. A (2014). Quantitative ethnozoological assessment of traditionally used animal based therapies in the tropical island of Mauritius. J Ethnopharmacol 154(3): $847-57$.

22. Verma AK, Prasad SB, Rongpi T \& Arjun J (2014). Traditional healing with animals (zootherapy) by the major ethnic group of Karbi Anglong district of Assam India. Inter J Pharm Pharm Sci 6: $1-8$.

23. Trivedi PC (2002). Ethnobotany: an overview. In Ethnobotany edited by: Trivedi PC. Jaipur: Aavishkar publisher.

24. Mahawar MM, \& Jaroli DP (2007) Traditional knowledge on zootherapeutic uses by the Saharia tribe of Rajasthan India. $J$ Ethnobiol Ethnomed 3: 25-30.

25. Kim H \& Song MJ (2013). Ethnozoological study of medicinal animals on Jeju Island. Korea $J$ Ethnopharmacol 146: 75-82. 